\title{
The Effect of Branding Quality and Service Quality on Customer Satisfaction through Financial Technology (FinTech) at PT. WOM Finance Branch Rantauprapat
}

\author{
Fani Pramaswari ${ }^{1}$, Ade Parlaungan Nasution², Siti Lam'ah Nasution ${ }^{3}$ \\ ${ }^{1,2,3}$ Universitas Labuhanbatu, Indonesia \\ fannyprama22@gmail.com
}

\begin{abstract}
In today's digital era, service companies are competing to improve the quality of their companies. By providing good service to make it easier for consumers to be more loyal, one form of strategy that is currently being carried out by service companies. PT WOM Finance provides a much better service to further increase consumer loyalty to the company through Financial Technology (Fintech), which currently WOM Finance is much better for its branding. The influence of quality is what will make it easier for them to get maximum results every month. This research was conducted by means of the Normality assessment test with five variables of Branding Quality, Service Quality, Customer Satisfaction, and the Intervening Fintech Variable with the number of respondents as many as 150 customers. The results of this study indicate that partially the quality of branding, service quality on customer satisfaction through financial technology has a significant effect on customer participation by increasing the company's profit.
\end{abstract}

Keywords

branding quality; service quality; customer satisfaction; fintech

\section{Introduction}

Establishing a good communication between companies and potential customers through the Branding program is important because the quality of Branding determines the success of a company in maintaining the quality of marketing so that effective distribution activities and providing satisfaction with customers make excellence for the company. In that case, many market competitors are looking for ways to maintain quality and consumers to be loyal to the company. An effective marketing program combines all elements of the marketing mix into a program designed to achieve the company's marketing goals by providing value to consumers

PT. Wahana Ottomitra Multiartha, which had the initial name PT. Jakarta Tokyo Leasing was established in 1982 which is engaged in service companies such as motorcycle financing, car financing by guaranteeing the BPKB of the vehicle and new motorcycle loans assisted by dealer partners. PT WOM Finance Cab Rantauprapat itself was also founded in 2012 in Labuhanbatu by working on the Labuhanbatu, South Labuhanbatu and North Labuhanbatu areas. An effective marketing program combines all elements of the marketing mix into a program designed to achieve the goals of a healthy company marketing by providing value to consumers. Establishing good communication between the company and consumers through providing promotional programs is very important because promotion or branding determines the success of a company's marketing program which can be done in various ways such as: advertising, personal selling, direct canvasing selling, publicity, and sales promotion. 


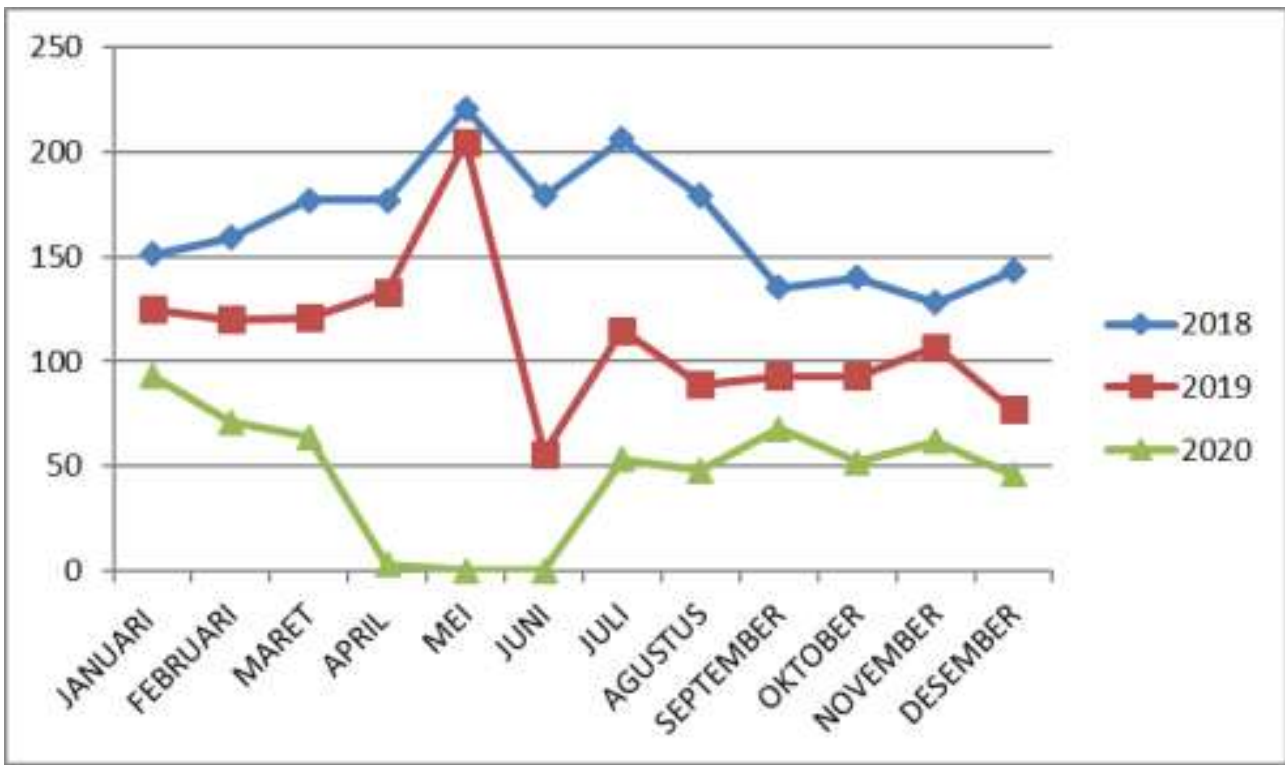

Source: Rekapan Jualan January 2018 - December 2020 PT WOM Finance

From the graph above, there was a drastic decline in 2020, with the condition of the Covid-19 Pandemic, PT WOM Finance held sales by reason of focusing on billing first, in May and June 2020 PT WOM Finance did not sell aka STOP SALE for 2 months the rest in July - December is back to normal with unstable graphs. Therefore PT WOM Finance made a strategy to increase sales with quality branding and service quality through Faintech which was carried out in order to increase its WOM assets.

Customer satisfaction is an important factor so that producers do not lose loyal customers to the company and can increase the number of new prospective customers. Everyone has a different level of satisfaction (Syamsuri \& Siregar, 2018). If consumers are not satisfied with the services provided by the company, the consumers are not satisfied and will switch to another company by offering offers provided by other companies. If the company meets a consumer's expectation, the satisfaction that consumers feel will be better. Based on observations and interviews with one of PT WOM Finance's customers, it is stated that the leasing process at PT WOM Finance is very safe, comfortable, can give trust to customers and the process is very easy / fast. Some customers also stated that PT WOM Finance employees were very helpful with the process until it was finished. During the field of marketing, you must have a communication strategy and marketing strategy, you need an ability to look ahead to see what is happening within the company in order to maintain and maintain relationships with customers.

The trade promotion factor is very influential on the interest of consumers who will buy products by providing attractive offers in order to attract consumers' intention to buy the products we market, moreover PT WOM FINANCE sells services, of course, the way of offering is different from selling goods. The decision of the consumer buyer has several considerations, including the decision about the type of product, the form of the product, the time of purchase and the method of payment. The product purchased must be of high quality so that consumers feel the product purchased is of high quality if the product can meet the wants and needs as expected or exceeds what is expected.

Kotler \& Keller (2012) defines customer loyalty as the consistency of customers in using their funds to buy products / services from the same brand or Provider Company. Customer loyalty can be seen through three perspectives, namely attitude, behavior, and 
integrative perspectives (Tjiptono \& Diana, 2015). There are three aspects compiled by Kotler \& Keller (2012). to measure customer loyalty, among others: (1) Word of mouth (recommending to others); (2) Reject another (reject another brand); and (3) Repeat purchasing. Previous studies have shown that one of the factors that affect customer loyalty is service quality (Wiharyo \& Budiarti, 2017; Meitiana, 2014). Service quality is a measure of the assessment of the service provided, whether it is able to meet customer expectations or not (Lewis \& Booms in Tjiptono \& Chandra, 2016).

Sangadji \& Sopiah (2013) explained that good service quality from a company can lead to feelings of satisfaction in customers which are then able to increase customer loyalty. The five dimensions of service quality compiled by Parasuraman, Zeithaml \& Berry, include reliability or reliability, responsiveness or responsiveness, assurance or assurance, empathy or empathy, and tangible or physical form (in Zeithaml, Bitner \& Gremler, 2013). In addition, another factor that can affect customer loyalty is emotional branding. Devina \& Andreani's research (2015) shows that there is a positive relationship between emotional branding and customer loyalty. Emotional branding is a channel that connects customers and companies and their products unconsciously through positive emotional relationships (Gobe, 2005).

\section{Review of Literature}

\subsection{Quality Branding}

The word Brand has its own term that can be interpreted as self-identity that differentiates between people, both humans, products and places. Meanwhile, Branding is a communication activity, strengthening, maintaining a brand in order to provide perspective to others who see it. Branding is not just a brand or trade name of a product, service or company. However, everything is related to the things that are visible to a brand, starting from the trade name, logo, visual characteristics, image, credibility, character, impressions, perceptions, and perceptions that are in the minds of consumers of the company (Landa 2006). The definition of branding is the provision of names, terms, signs, symbols, designs, or a combination of these, which are made with the aim of identifying goods or services or groups of sellers and to differentiate them from competing goods or services (Kotler 2009)

\subsection{Service Quality}

Service is an overall process of forming a company image, either through the news media, forming an internal corporate culture, or communicating about the company's views to government leaders and other interested publics. According to Moenir in his book Public Service Management in Indonesia, says that: "Service is the process of meeting needs through the activities of other people directly." (Moenir, 1992: 16). Emphasis on the definition of service above is the service provided regarding all efforts made by a person in order to achieve goals in order to get satisfaction in terms of meeting needs. Meanwhile, Brata issued a different definition in his work entitled Basics of Excellent Service, saying that: "A service will be formed due to a certain service delivery process from the service provider to the service provider." (Brata, 2003: 9).

To get a lot of consumers, one way to do this is to create customer loyalty (Harahap, 2021). Service quality and innovation are two elements that can build competitive advantage, because the quality of service as a infrastructure that is adequate in providing services, while innovation is applied because consumers want a renewal in the services 
perceived by consumers, so the end result of service quality and innovation is the creation of competitive advantage (Kusumadewi, 2019).

\subsection{Customer Satisfaction}

Satisfaction is an attitude that is decided based on the experience gained. Satisfaction is an assessment of the characteristics or features of a product or service, or the product itself, which provides a level of consumer pleasure related to meeting consumer consumption needs. Customer satisfaction can be created through quality, service and value. The key to producing customer loyalty is to provide high customer value (Lovelock and Wirtz (2011: 74). Siregar et al., (2020) said that satisfaction is a positive attitude or feeling positive for everything person received. According to Tjiptono (1997: 24) customer satisfaction or dissatisfaction is the customer response to the evolution of a perceived discrepancy (discinfirmation) between previous expectations and the actual performance of the product. It is felt that in this increasingly fierce competition, more and more producers are involved in fulfilling the needs and desires of consumers so that this causes every business entity to place an orientation towards customer satisfaction as the main goal, among others, with the increasing number of business entities that declare their commitment to customer satisfaction. in mission statements, advertisements

The factors that drive customer satisfaction (Hendy Irawan Juwandi, 2004: 37) are as follows :

1. Product quality, customers will be satisfied if after buying and using the product it turns out that the product quality is good.

2. Price, for sensitive customers, usually low prices are an important source of satisfaction because customers will get high value for money.

3. Service quality, satisfaction with service quality is generally difficult to imitate. Service quality is a driver that has many dimensions, one of which is popular is servqual

4. Emotional Factor, customers will feel satisfied (proud) because of the emotional value provided by the brand of the product

5. Cost and convenience, customers will be more satisfied if it is relatively easy, comfortable and efficient in obtaining products or services.

\subsection{Financial Technology (FinTech)}

In the current digital economy era, the use of technology is increasing (Siregar et al., 2019). Based on Pribadiono, Hukum, Esa, \& Barat (2016), Financial Technology (FinTech) is a combination of technology and financial features or it can also mean innovation in the financial sector with a touch of modern technology. According to Dorfleitner, Hornuf, Schmitt, \& Weber (2017), FinTech is a very fast-moving and dynamic industry where there are many different business models. According to Hsueh (2017), Financial Technology, also referred to as FinTech, is a new financial service model developed through information technology innovation. Fitntech Weekly FinTech is a line of business based on the use of software to provide financial services. Financial technology companies are generally startups founded with the aim of disrupting financial system incumbents and companies that rely on less software. Arner et al. (2015) FinTech refers to the use of technology to deliver financial solutions. According to the NDRC (National Digital Research Center) Fintech is a term to describe new breakthroughs in the field of financial services. In simple terms, it can be interpreted as a breakthrough in finance that involves advanced technology 


\subsection{Literature Review and Relationship between Variables}

\section{a. Analysis of Branding Quality on customer satisfaction through Fintech}

Tjiptono, (1997,104) argues that a brand is a name, term, sign, symbol / symbol, design, color, motion or a combination of other product attributes that are expected to provide identity and differentiation to competitor's products. Meanwhile, Durianto, et al. $(2001,1)$ argues that a brand is a name, term, sign, symbol, design or a combination thereof which identifies a product or service produced by a company.

\section{b. Analysis of Service Quality on customer satisfaction through Fintech}

Interest as a mediator has not been widely used in previous studies. Departing from the service quality theory developed by Cronin and Taylor (1992) which explains that consumer expectations are formed through consumer interest so that it affects the quality of service obtained by consumers. According to Yarimoglu (2014) service quality is formed by knowledge of the service. Increasing consumer knowledge tends to encourage high consumer interest in using a service. Furthermore, the quality of service obtained will be adjusted to the expectations built through the information received by consumers. Thus this study argues that knowledge accompanied by interest can affect the quality of service received by consumers.

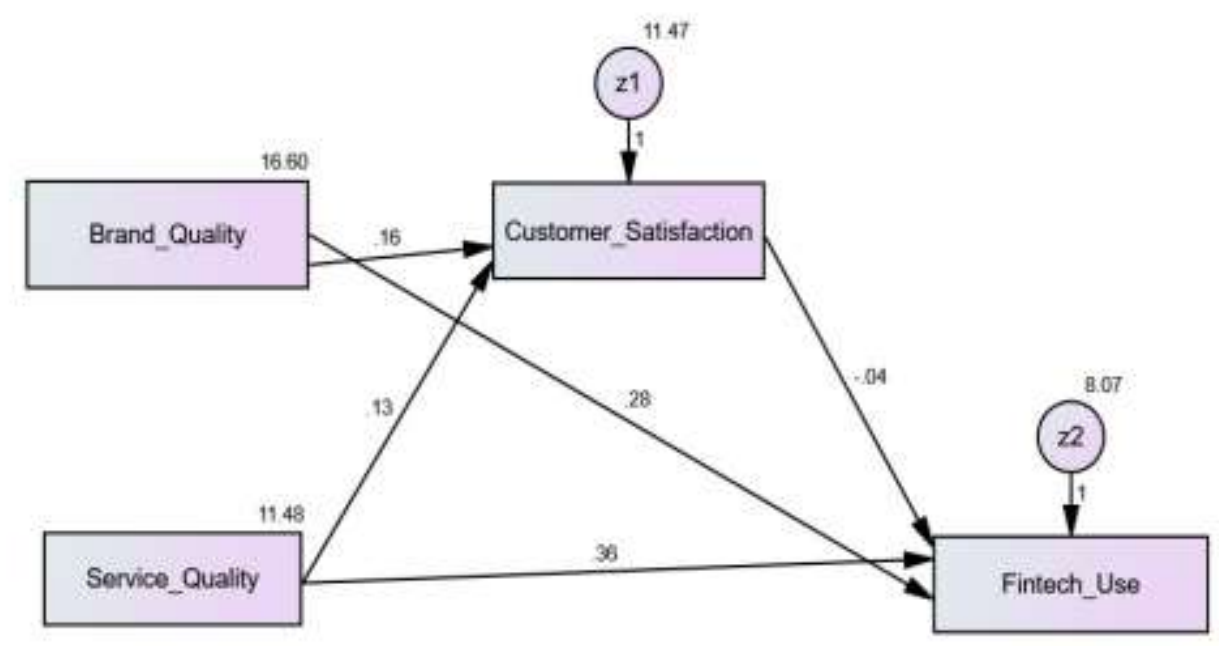

\section{Research Methods}

Research location at PT WOM FINANCE Branch Rantauprapat. The research object is direct customers who come to the office. The data collection method is a questionnaire. amounting to 150 employees. Reliability is a dimension that shows the ability of the company's employees to provide the promised service immediately, accurately and satisfactorily. Responsiveness is the desire or willingness of employees to respond to customer needs or complaints. Guarantees include knowledge, courtesy and skills possessed by employees that can give a customer confidence. Empathy is an attitude of caring that is carried out by employees by paying more attention to customers. Gender differences are a very meaningful part of identity for individuals, because with gender it can be seen whether a person is classified as male or female (Fakih, 2003). The measurement scale is carried out using a Likert scale, namely 1-5 (1: strongly disagree, 2 : disagree, 3: neutral, 4: agree, 5: strongly agree). The groups in this study are male and female consumers. The data analysis technique used in this study uses path analysis techniques with the help of AMOS Version 23. Distribution process the questionnaire is 
carried out directly when consumers come to the Rantauprapat branch office. The variables in this study consists of four variables, namely branding quality, service quality, customer satisfaction with Fintech intervening variables.

\section{Results and Discussion}

\subsection{Result}

\section{a. Assessment of Normality}

The normality test aims to test whether the data is normally distributed or not. A good regression model is normally distributed or close to normal. The results of the normality test as shown in Table 1 indicate that C.R. of $-1,288$. This shows that there is data that is normally distributed. For more details, see Table 1 below:

Table 1. Assessment of normality

\begin{tabular}{|l|rrrrrr|}
\hline Variable & $\min$ & $\max$ & skew & c.r. & kurtosis & c.r. \\
\hline $\begin{array}{l}\text { Service } \\
\text { quality }\end{array}$ & 19.000 & 36.000 & -.171 & -.854 & -.311 & -.776 \\
$\begin{array}{l}\text { Quality } \\
\text { Branding }\end{array}$ & 25.000 & 44.000 & -.212 & -1.059 & -.554 & -1.385 \\
$\begin{array}{l}\text { Customer } \\
\text { Satisfaction }\end{array}$ & 27.000 & 44.000 & -.454 & -2.272 & -.043 & -.108 \\
$\begin{array}{l}\text { Fintech } \\
\text { Multivariate }\end{array}$ & 11.000 & 28.000 & -.631 & -3.156 & -.180 & -.451 \\
& & & & & -1.457 & -1.288 \\
\hline
\end{tabular}

\section{b. Regression Weights}

This study has five hypotheses which are tested using path analysis techniques. Path Analysis is a direct development of some form of regression to determine the direct or indirect effect of a set of independent variables on related variables. Hypothesis testing is carried out using a P-value with a significance level of 0.05. The Pv value in the IBM SPSS AMOS version 23 program is the Critical Ratio (C.R.) value. If the value of Critical Ratio (C.R.) > 1.96 or the probability value $(\mathrm{P})<0.05$ then $\mathrm{H} 0$ is rejected (the research hypothesis is accepted).

Table 2. Regression Weights

\begin{tabular}{|c|c|c|c|c|c|c|c|}
\hline & & & Estimate & S.E. & C.R. & $\mathrm{P}$ & Label \\
\hline $\begin{array}{l}\text { Customer } \\
\text { Satisfaction }\end{array}$ & $<---$ & Quality Branding & .183 & .068 & 2.297 & .022 & par_1 \\
\hline $\begin{array}{l}\text { Customer } \\
\text { Satisfaction }\end{array}$ & $<---$ & Service quality & .130 & .082 & 1.633 & .102 & par_5 \\
\hline Fintech & $<---$ & Quality Branding & .346 & .058 & 4.779 & $* * *$ & par_2 \\
\hline Fintech & $<---$ & Service quality & .369 & .069 & 5.144 & $* * *$ & par_3 \\
\hline Fintech & $<---$ & $\begin{array}{l}\text { Customer } \\
\text { Satisfaction }\end{array}$ & -.043 & .069 & -.586 & .558 & par_4 \\
\hline
\end{tabular}




\section{c. The Results of the Hypothesis Test}

\section{Hypothesis Examiner 1}

The examiner of the first hypothesis has a significant and positive influence between quality branding. The results of the research show that for the t value (C.R.) from 2.297> 1.96 with a P-value of $0.000<0.05$. This means that $\mathrm{H} 0$ is rejected and $\mathrm{Ha}$ accepted, in this case it shows that there is a significant and positive influence between service qualities

\section{Hypothesis Examiner 2}

The examiner of the second hypothesis has a significant and positive influence between customer satisfaction. The results of the research show that for the $t$ value (C.R.) from 1.633> 1.96 with a P-value of $0.000<0.05$. This means that $\mathrm{H} 0$ is rejected and $\mathrm{Ha}$ accepted, in this case it shows that there is a significant and positive influence between service quality.

\section{Hypothesis Examiner 3}

The third hypothesis examiner has a significant and positive influence between quality branding. The results of the research show that for the t value (C.R.) from 4.779> 1.96 with a P-value of $0.000<0.05$. This means that $\mathrm{H} 0$ is rejected and $\mathrm{Ha}$ accepted, in this case it shows that the influence is significant and positive between Fintech

\section{Hypothesis Examiner 4}

The examiner of the fourth hypothesis has a significant and positive influence between customer satisfaction. The results of the research show that for the t value (C.R.) from 5,114> 1.96 with $\mathrm{P}$-value $0.000<0.05$. This means that $\mathrm{H} 0$ is rejected and $\mathrm{Ha}$ accepted, in this case it shows that the influence is significant and positive between Fintech

\section{Hypothesis Examiner 5}

The examiner of the fourth hypothesis has a significant and positive influence between service quality. The results of the research show that for the $t$ value (C.R.) from $.586>1.96$ with $\mathrm{P}$-value $0.000<0.05$. This means that $\mathrm{H} 0$ is rejected and Ha rejected, in this case it shows that the influence is insignificant and not positive between Fintech

\subsection{Discussion}

This study the effect of branding quality, service quality on customer satisfaction through Fintech conducted at PT. WOM Finance Rantauprapat Branch uses path analysis. first hypothesis testing shows that the quality of branding significantly affects the quality of service at WOM Finance Rantauprapat Branch. This shows that the quality of branding in the company has been maximized, so the quality of service will be good Conversely, if the quality of branding is not optimal, the quality of service is also bad. Research has been conducted before Octafiana (2015) which states that brand image variable has a positive and significant effect on service quality and is supported by Ovie's research (2013) which states that brand image has a positive effect and significant impact on customer quality. Described again by Essiam (2013: 49) Quality of service which can be satisfied consumers include; physical evidence, reliability, responsiveness, assurance, and empathy.

The second hypothesis examiner shows that customer satisfaction has a significant effect on service quality. It can be interpreted that if the existing customer satisfaction is improved so far, the customer will be highly qualified. However, if the quality of service is not improved, then customer satisfaction will decrease with the company. The findings of 
this study enter according to Ishaq (2012) Auka (2012); and Chen and Tsai (2008). Shows the value the customer received significantly influence loyalty customer.

The third hypothesis testing shows that the quality of branding has a significant effect on Fintech. In this case, it can be argued that the better the branding quality, the more Fintech users in the company are Conversely, if the quality of branding decreases or is not good, then fewer people will use Fintech. The fourth hypothesis testing shows that customer satisfaction has a significant effect on fintech. In this case, it can be argued that the more consumers are satisfied with the service, the more Fintech users are in the company. Conversely, if consumers are not satisfied, then less and less will use Fintech. Previous research that has been discussed on the hypothesis is by Dahlia Br Ginting and Meida Riana Marlina (2017) who state that ease of use has an effect positive on customer satisfaction.

The fifth hypothesis testing shows that service quality has no significant effect on fintech. in this case what happens in the field at the time of the survey directly with consumers. There are indeed many professional consumers as farmers who may not have known Fintech before, therefore this research has not been thoroughly examined by previous researchers.

\section{Conclusion}

Based on the results of the research analysis, it can be seen that the quality of branding which will improve the quality of service in the company has a positive impact on customer satisfaction. Not only the quality of branding, the quality of service must also be of particular concern to the company to increase the company's selling value in terms of sales and existing brands. Moreover, by increasing customer satisfaction, it will be easier for companies to get good results. But the same is contrary to the quality of service to Fintech because consumers still do not know the Fintech that is at PT WOM Finance, therefore the company must explain in more detail or socialize via Social Media so that it can be accepted by the Labuhanbatu Community, especially those who are farmers. With that the company can be easier and more efficient with the quality of service and consumers are also easier and happy with the socialization provided by the company. With this research, it will be a correction by PT WOM Finance to further improve its Fintech in order to make it easier for them to gain profit every month, not to bother to achieve it all, and to make the Labuhanbatu community prosperous towards their financing.

\section{References}

Aditya Arta, M. H. (n.d.). Analisis Penetapan Strategi Bisnis Dan Posisi Persaingan Pt. Wom Finance Jakarta, 99 -117.

Apriansyah, R. (2019). Eko dan Bisnis: Riau Economic. Pengaruh Strategi Pemasaran Dan Pelayanan Penjualan Terhadap Kepuasan Pelanggan Pada Pt. Wom Finance Kecamatan Pasir, https://ekobis.stieriauakbar.ac.id/index.php/Ekobis/article/view/201.

Aryani, D. (2010). Jurnal Ilmu Administrasi dan Organisasi. Pengaruh kualitas layanan terhadap kepuasan pelanggan dalam membentuk loyalitas pelanggan, 114-126.

Chusnah, K. T. (2020). Pengaruh Kemudahan Dan Keamanan Terhadap Kepuasan Konsumen Fintech, 1-9. 
Dyah Retno Maftukhah, I. (2017). Vol. 6. Pengaruh Kualitas Layanan, Citra Merk Dan Inovasi Layanan Terhadap Kepuasan Pasien Rawat Inap Pada Rs Keluarga Sehat Di Kab Pati, 76-82.

Entaresmen, R. A. (2017). Jurnal Manajemen dan Pemasaran Jasa. Strategi Pemasaran Terhadap Penjualan Produk Tabungan Ib Hasanah Di Pt. Bank Negara Indonesia Syariah Kantor Cabang Jakarta Barat, 53.

Gede Marendra, I. (2018). Pengaruh Bauran Pemasaran (Produk, Harga, Lokasi Dan Promosi) Terhadap Keputusan Pembelian Konsumen Di Minimarket (Alfamart Atau Indomaret), 2598-823.

Harahap, I., Nasution, Y.S.J., and Chairina. (2021). Analysis of Muslim Customer Loyalty Shopping for Fashion in the Traditional Inpres I Market in Kisaran. Budapest International Research and Critics Institute-Journal (BIRCI-Journal) Vol 4 (1): 2838.

Komariah, N. R. (2016). Record and Library Journal. Emotional Branding sebagai Upaya Pengembangan Kualitas Layanan Perpustakaan untuk Meningkatkan Penggunaan Perpustakaan, 188-197.

Kusuma, E. C. (2018). Jurnal Bisnis dan Manajemen. Pengaruh Nilai Yang Diterima Pelanggan Dan Kualitas Pelayanan Terhadap Loyalitas Pelanggan : Kepuasan Pelanggan Sebagai Mediator Dan Gender Sebagai Moderator, 42-50.

Kusumadewi, R.N., Karyono, O. (2019). Impact of Service Quality and Service Innovations on Competitive Advantage in Retailing. Budapest International Research and Critics Institute-Journal (BIRCI-Journal) Vol 2, (2): 366-374.

Mohamad Rizan, F. A. (2011). Pengaruh Kualitas Produk Dan Kualitas Pelayanan Terhadap Kepuasan Pelanggan (Survei Pelanggan Suzuki, Dealer Fatmawati, Jakarta Selatan).

Mois, F. A. (2020). Pengaruh strategi pemasaran terhadap niat pembelian ulang melalui kepuasan konsumen pada fintech syariah.

Oliver, J. (2013). Vol.53. Journal of Chemical Information and Modeling, 1689-1699.

Permana, M. V. (2013). Peningkatan Kepuasan Pelanggan Melalui Kualitas Produk Dan Kualitas Layanan, 115-131.

Purnomo, A. (2018). Jurnal Jibeka Volume 12. Digital Marketing Terhadap Loyalitas Pelanggan ( Studi pada Pelanggan Kedai Hj . S J1 . Kesumba Kota Malang ), 1-8.

Putra, Y. A. (2020). Implementasi Komunikasi Pemasaran Dalam Mempertahankan Hubungan Pelanggan Di PT . WOM Finance .

Rohmaningtyas, M. N. (2016). New Scientist Vol. 165. Pengaruh Brand Image, Kualitas Pelayanan Dan Kepuasan Nasabah Terhadap Loyalitas Nasabah Di Lembaga Keuangan Mikro Syariah, 57.

Rosinta, D. A. (2010). Program Studi Ilmu Administrasi Departemen FISIP, Universitas Indonesia. Pengaruh Kualitas Layanan terhadap Kepuasan Pelanggan dalam Membentuk Loyalitas Pelanggan.

Sari, N. P. (2019). Analitika : Jurnal Magister Psikologi UMA Vol. 11. Layanan dan emotional branding airlines customer loyalty reviewed from service quality and emotional branding, 98-103.

Siregar, Z. M. E., Suryana, Ahman, E., \& Senen, S. H. (2019). Does knowledge management enhance innovation: A literature review. International Journal of Scientific and Technology Research, 8(9), 1991-1994.

Siregar, Z. M. E., Syahputra, R., \& Nasution, S. L. (2020). Pengaruh Keadilan Organisasional terhadap Komitmen Organisasi: Peran Mediasi Kepuasan Kerja. JSHP ( Jurnal Sosial Humaniora Dan Pendidikan), 4(2), 82-92. 
Syamsuri, A. R., \& Siregar, Z. M. E. (2018). Analisis Pelatihan, Disiplin Kerja, Remunerasi, dan Motivasi Berprestasi dengan Kepuasan Kerja Sebagai Variabel Intervening terhadap Kinerja Karyawan. JSHP ( Jurnal Sosial Humaniora Dan Pendidikan), 2(2), 95. https://doi.org/10.32487/jshp.v2i2.470

Syarif, K. (2010). Dosen Fakultas Ekonomi Universitas Pakuan. Analisis Brand Image Terhadap Kepuasan Pelanggan. 